\title{
PENERAPAN METODE PERMUKAAN RESPONS DALAM MASALAH OPTIMALISASI
}

\author{
Ade KuSUma DeWI ${ }^{1}$, I WAYAN SUMARJAYA ${ }^{2}$, \\ I GUSTI AYU MADE SRINADI ${ }^{3}$

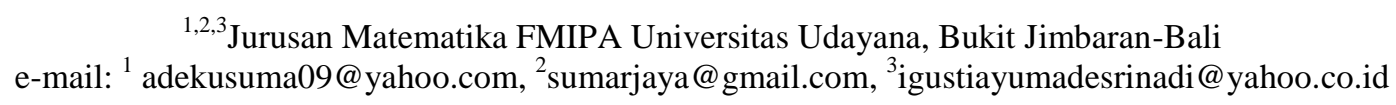

\section{Abstract}

The experiments were conducted to determine the relationship between response variable and independent variable and the effect of independent variables to response variable. Multiple comparison tests can be used to find the level that makes optimal response. However, this test has a drawback that it only finds the optimal level tested at the level being considered. Thus test is more suitable for qualitative independent variables. On the other hand, for quantitative independent variables we can use the orthogonal polynomial method and response surface method (RSM).The purpose of this research is to apply RSM to produce optimal response. It can be concluded that RSM is an efficient used to find the level of independent variables to makes optimal response.

Keywords: Experiments Design, Response Surface Method.

\section{Pendahuluan}

Percobaan merupakan hal yang sering dilakukan dalam berbagai bidang ilmu. Tujuan suatu percobaan adalah untuk mendapatkan informasi yang maksimum tentang peubah-peubah bebas yang memengaruhi respons (Steel and Torrie [4]). Rancangan percobaan merupakan gabungan antara rancangan lingkungan dan rancangan perlakuan. Rancangan lingkungan diantaranya adalah rancangan acak lengkap (RAL), rancangan acak kelompok (RAK), dan rancangan bujur sangkar latin (RBSL), sedangkan yang termasuk rancangan perlakuan diantaranya rancangan satu faktor, faktorial, dan rancangan split blok. Rancangan percobaan tersebut menggunakan analisis varians untuk melihat peubah bebas atau interaksi dari peubah bebas yang berpengaruh signifikan terhadap respons. Peubah bebas atau interaksi yang berpengaruh signifikan terhadap respons akan diuji lebih lanjut dengan uji perbandingan berganda diantaranya BNT, BNJ, Duncan atau Tukey digunakan untuk memilih taraf yang dapat membuat respons optimal, namun pemilihan taraf hanya terbatas pada taraf-taraf yang dicobakan saja sehingga metode ini lebih cocok digunakan untuk peubah bebas yang bertaraf kualitatif karena tidak ada nilai optimal yang berada di luar taraf yang dicobakan.

Untuk peubah bebas yang bertaraf kuantitatif, metode yang digunakan untuk mendapatkan respons yang optimal adalah metode polinomial ortogonal dan

\footnotetext{
${ }^{1}$ Mahasiswa Jurusan Matematika FMIPA Universitas Udayana

${ }^{2,3}$ Staf Pengajar Jurusan Matematika FMIPA Universitas Udayana
} 
metode permukaan respons. Metode polinomial orthogonal lebih efisien digunakan untuk peubah bebas yang memiliki jarak antarfaktor yang sama, karena nilai dari koefisien bentuk kontras polynomial sudah baku dan ditabelkan. Sedangkan untuk peubah bebas yang memiliki jarak antarfaktor yang berbeda nilai dari kontras polynomial sangat sulit untuk dicari. Untuk mengatasi masalah tersebut, maka dapat digunakan metode permukaan respons. Metode permukaan respons digunakan untuk mencari taraf-taraf peubah bebas yang dapat mengoptimalkan respons (Montgomery [2]). Metode ini memerlukan data yang tidak terlalu banyak, sehingga kondisi optimum respons dapat diperoleh dengan waktu yang tidak terlalu lama dan biaya yang minimum [3].

Penelitian ini bertujuan untuk menentukan kondisi optimal respons dengan menerapakan metode permukaan respons. Dengan contoh kasus mencari waktu filtrasi proses kimia minimum yang dipengaruhi oleh suhu dan tekanan.

\section{Metode Penelitian}

Data yang digunakan sebagai contoh kasus dalam penelitian ini adalah data sekunder. Data diambil dari buku Montgomery (1991) yang merupakan data tentang waktu filtrasi proses kimia yang dipengaruhi oleh suhu dan tekanan dalam bentuk kode. Selanjutnya nilai taraf dari masing-masing peubah bebas akan diasumsikan.

Pengolahan data pada penelitian ini menggunakan bantuan software Minitab. Dengan langkah-langkah yaitu menetapkan taraf masing-masing peubah bebas, merancang percobaan orde I, melakukan analisis varians, pencarian taraf di sekitar daerah optimal dengan metode steepest ascent atau steepest descent apabila dalam analisis varians uji simultan signifikan dan model yang didapat sesuai, merancang percobaan orde II, melakukan analisis varians, mencari lokasi titik stationer, menentukan karakteristik titik stasioner, menentukan nilai respons optimal.

\section{Hasil dan Pembahasan}

Peubah respons dalam penelitian ini adalah waktu filtrasi proses kimia (dalam menit) yang dipengaruhi oleh suhu $\left(X_{1}\right)$ dan tekanan $\left(X_{2}\right)$. Dalam penelitian ini suhu yang ingin diteliti yaitu dengan interval $210-230{ }^{0} \mathrm{C}$ dan tekanan 54-58 Mpa. Dilakukan dua tahap percobaan dalam metode permukaan respons, yaitu percobaan orde I dan percobaan orde II. Percobaan orde I, memerlukan rancangan percobaan yang terdiri dari rancangan faktorial $2^{\mathrm{k}}\left(n_{f}\right)$, dan rancangan titik pusat (Montgomery [2]).

Rancangan faktorial terdiri dari kombinasi taraf terendah dan taraf tertinggi masing-masing peubah bebas dan rancangan titik pusat terdiri dari kombinasi nilai tengah dari peubah bebas. Dari rancangan percobaan orde I diperoleh data seperti berikut 
Tabel 1. Rancangan Percobaan Orde I

\begin{tabular}{|c|c|c|c|}
\hline No & Suhu & Tekanan & Waktu Filtrasi \\
\hline 1 & 210 & 54 & 53 \\
\hline 2 & 210 & 58 & 45 \\
\hline 3 & 230 & 54 & 32 \\
\hline 4 & 230 & 58 & 47 \\
\hline 5 & 220 & 56 & 39 \\
\hline 6 & 220 & 56 & 41 \\
\hline 7 & 220 & 56 & 44 \\
\hline 8 & 220 & 56 & 42 \\
\hline 9 & 220 & 56 & 40 \\
\hline
\end{tabular}

Sebelum dianalisis, data pada Tabel 1 harus dikodekan terlebih dahulu dengan kode 1 dan -1 masing-masing menyatakan taraf tertinggi dan terendah dari masing-masing peubah bebas. Kode 0 menyatakan nilai titik tengah kedua taraf tersebut. Hasil uji parsial dalam percobaan orde I didapat nilai p-value untuk suhu dan tekanan yaitu 0,122 dan 0,533 lebih besar dari nilai $\alpha(0,05)$ sehingga dapat dinyatakan bahwa suhu dan tekanan tidak berpengaruh signifikan terhadap respons. Sedangkan dari hasil analisis varians, ada dua uji yang akan dilakukan untuk memeriksa signifikansi yaitu uji simultan dan uji lack of fit.

Hasil analisis varians untuk uji simultan didapat p-value yaitu 0,239>0,05 maka dapat disimpulkan bahwa peubah bebas secara bersama-sama tidak berpengaruh signifikan terhadap respons. P-value untuk uji lack of fit didapat $0,008<0,05$ maka sesuai dengan hipotesis lack of fit yaitu:

$$
\begin{gathered}
H_{0}: \text { Model regresi cocok (tidak ada lack of fit) } \\
H_{1} \text { : Model regresi tidak cocok (ada lack of fit) }
\end{gathered}
$$

Sehingga adanya penolakan $H_{0}$, maka dapat disimpulkan model yang digunakan dalam percobaan orde I belum sesuai (tidak cocok). Karena dalam analisis varians uji simultan tidak signifikan dan model yang didapat belum sesuai maka percobaan akan dilanjutkan dengan melakukan pendugaan pada model yang lebih tinggi yaitu model orde II.

Rancangan yang digunakan dalam percobaan orde II adalah rancangan faktorial $2^{\mathrm{k}}$, rancangan titik pusat dan rancangan axial runs. Rancangan axial runs adalah rancangan dengan kombinasi nilai $\pm \alpha^{*}$ dengan nilai titik tengah. Nilai $\pm \alpha^{*}$ didapat dari $\alpha^{*}=\left(n_{f}\right)^{\frac{1}{4}}$, untuk kasus ini $n_{f}=2^{2}=4$, dengan demikian diperoleh $\alpha^{*}=4^{\frac{1}{4}}= \pm 1,414$. Nilai dari $\pm \alpha^{*}$ perlu diubah menjadi nilai taraf sebenarnya dengan menggunakan persamaan:

$$
X_{k}=\frac{\text { Taraf sebenarnya }-\frac{\text { taraf tertinggi }+ \text { taraf terenda } h}{2}}{\frac{\text { taraf tertinggi }- \text { taraf terenda } h}{2}}
$$

dengan $X_{k}$ menyatakan peubah bebas yang dikodekan (Kutner, et al., [1]). Maka 
data yang digunakan dalam percobaan orde II adalah data pada Tabel 1 ditambah dengan rancangan axial runs berikut

Tabel 2. Rancangan Axial Runs

\begin{tabular}{|c|c|c|c|}
\hline No & Suhu & Tekanan & Waktu Filtrasi \\
\hline 1 & 206 & 56 & 50 \\
\hline 2 & 234 & 56 & 40 \\
\hline 3 & 220 & 53 & 43 \\
\hline 4 & 220 & 59 & 46 \\
\hline
\end{tabular}

Hasil analisis pada percobaan orde II, untuk uji parsial didapat nilai p-value yang lebih kecil dari nilai $\alpha=0,05$ untuk semua peubah bebas dan interaksinya, sehingga dapat disimpulkan semua peubah bebas dan interaksinya berpengaruh signifikan terhadap respons. Untuk analisis varians didapat nilai p-value untuk uji simultan yaitu 0,000 lebih kecil dari $\alpha$, sehingga dapat disimpulkan bahwa secara bersama-sama peubah bebas baik secara linear, kuadrat dan interaksi berpengaruh signifikan terhadap respons.

P-value untuk uji lack of fit didapat 0,763 lebih besar dari nilai $\alpha$, sehingga dapat disimpulkan bahwa model yang didapat sesuai (cocok). Apabila dilihat dari uji simultan dan uji lack of fit maka model pada percobaan orde II dikatakan sesuai.

Tahap selanjutnya akan dilakukan pencarian lokasi titik stationer dengan menggunakan $x_{s}=-\frac{1}{2} B^{-1} b$. Titik stasioner yang didapat dalam penelitian ini adalah $X_{1,0}=-0,925$ dan $X_{2,0}=-1,3$. Selanjutnya akan dilihat karakteristik dari titik stationer tersebut yang dapat dilihat dari plot permukaan respons berikut.

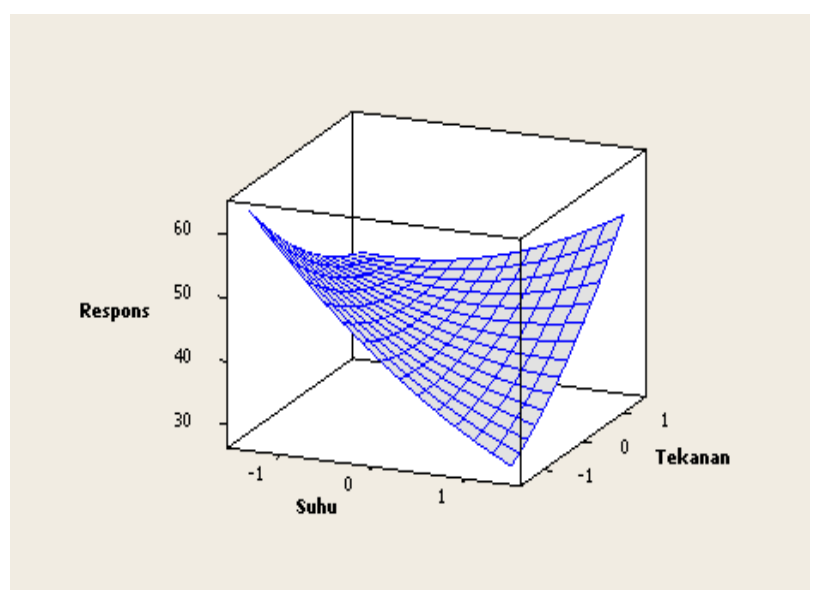

Gambar 1. Plot Permukaan Respons

Dari gambar plot permukaan respons tersebut dapat dilihat bahwa karakteristik yang dimiliki oleh titik stationer pada percobaan ini adalah titik pelana. Apabila titik stationer yang didapat digunakan untuk menduga nilai respons, maka tidak akan didapat nilai respons yang optimal.

Tujuan awal dari percobaan ini adalah untuk mendapatkan taraf dari peubah bebas yang dapat mengoptimalkan respons, yaitu meminimumkan waktu filtrasi 
proses kimia, namun tidak terpenuhi karena titik stationer yang didapat memiliki karakteristik titik pelana. Untuk mengatasi masalah tersebut maka dilakukan analisis pada contour plot sebagai berikut.

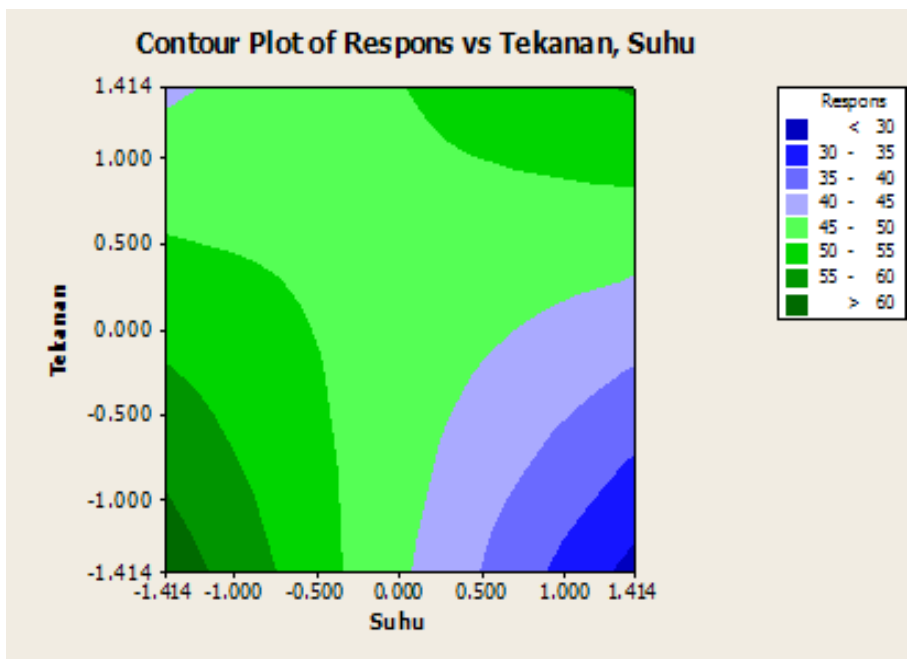

Gambar 2. Contour Plot

Berdasarkan Gambar di atas dapat disimpulkan bahwa nilai respons minimum yaitu kurang dari 30 menit dihasilkan dari suhu yang memiliki kode $1,414\left(234^{\circ} \mathrm{C}\right)$ dan tekanan yang memiliki kode -1,414 (53 Mpa).

\section{Kesimpulan}

Metode permukaan respons merupakan metode yang efisien digunakan untuk menentukan taraf-taraf peubah bebas yang dapat mengoptimalkan respons untuk peubah bebas yang bertaraf kuantitatif. Untuk mendapatkan waktu filtrasi minimum dalam contoh kasus ini, dipilih taraf untuk suhu dan tekanan masingmasing yaitu $234^{0} \mathrm{C}$ dan $53 \mathrm{Mpa}$.

\section{Daftar Pustaka}

[1] Kutner, Michael H., Chistopher J., J. Neter, and William Li. 2005. Applied Linear Statistical Models $5^{\text {th }}$ edition. Mc Graw- Hill, Boston.

[2] Montgomery, Douglas C. 1991. Design and Analysis of Experiments. John Wiley \& Sons, New York.

[3] Nuryati dan Salimy D. 2008. Metode Permukaan Respon dan Aplikasinya pada Optimal Eksperimen Kimia. Risalah Lokakarya Komputasi dalam Sains dan Teknologi Nuklir, 373-391.

[4] Steel, Robert G.D and James H. Torrie. 1995. Prinsip Dan Prosedur Statistika Edisi Kedua. Diterjemahkan oleh Bambang Sumantri. PT. Gramedia, Jakarta. 